\title{
Effectiveness, Efficiency and Growth Ratios on Financial Performance on Medan City Government
}

\author{
${ }^{1}$ Oktarini Khamilah Siregar, ${ }^{2}$ Andysah Putera Utama Siahaan \\ Universitas Pembangunan Panca Budi, Medan, Indonesia \\ Email: ${ }^{1}$ oktarini.khamilah@gmail.com, ${ }^{2}$ andiesiahaan@gmail.com
}

\begin{abstract}
Regional autonomy (decentralization) is the regional authority to regulate and manage the interests of society at its initiative based on community aspiration and according to laws and regulation. One aspect of local government that must be regulated carefully is the financial management area. To analyze the performance of local governments in managing local finances can be done with the financial ratio analysis. The financial ratios used include the effectiveness ratios, efficiency ratio, growth ratio and the ratio of independence. The purpose of this study is to determine the financial performance of Medan. Government significant effect on the ratio of independence. The population in this study is Medan Realization Report Government Budget in which samples are taken four years (2010/2013 in months January to December). The variables studied include the ratio of effectiveness, efficiency ratio and growth ratio as independent variables as well as the ratio of independence as a dependent variable. The results of the regression analysis showed that the ratio of effectiveness, effectiveness ratio, and growth ratio is evident from the 0,000 probability value of $<0.05$. Partial, effectiveness ratio has significantly influenced the ratio of independence. However, efficiency ratio and growth rate do not significantly influence the ratio of independence (budget financial field municipal government). Analysis of the coefficient of determination (R2) shows the number of 0.452 or equal to $45.2 \%$ which changes the city government performance ratio by the effect ratio, efficiency ratio and growth ratio, while the remaining $54.8 \%$ are likely influenced by other variables not examined in this study there are activity ratio, debt service cover ratio.
\end{abstract}

Key Words: effectiveness, efficiency, growth, performance.

\section{INTRODUCTION:}

Law No. 33 of 2004 concerning Financial Balance between the Central Government and Regional Governments, opens broad opportunities for regions to develop and develop their regions by their respective needs and priorities. In line with the enactment of the two laws, three packages of legislation were born, such as Law No. 17/2003 concerning State Finance, Law No. 1/2004 concerning State Treasury and Law No. 15/2004 concerning the Examination of the Management of State Financial Responsibilities, which has made fundamental changes in the administration of government and financial arrangements, particularly the Planning and Budget of the Regional and Central Government. Furthermore, because it is deemed necessary to implement a comprehensive and integrated regulation (omnibus regulation) of all laws and regulations concerning regional financial management, the Government has realized through PP No. 58 of 2005 concerning Regional Financial Management and the Ministry of Home Affairs Regulation 13 of 2006 concerning Guidelines for Regional Financial Management which aims to facilitate implementation and do not lead to multiple interpretations in their use.

Regional financial problems are one of the main elements in the implementation of regional autonomy. Although it is recognized that a variety of other variables also affect the ability of local finances, such as variables of human resources, organization, management, facilities and infrastructure and other supporting variables. Performance measurement is essential to assess the reliability of local governments in managing regional finances. Accountability is not just the ability to show how public money is spent, but includes the ability to show that public money is spent economically, effectively and efficiently. In the strategy system, performance measurement serves as an assessment tool whether the strategy that has been established has been successfully achieved.

Performance measurement is done to fulfill three purposes [1]. First, to help improve government performance. Second, to allocate resources and make decisions. Third, to realize public accountability and improve institutional communication. The financial performance is usually expressed by financial ratios identified from local government financial statements [2]-[5] One of the tools to analyze the performance of local governments in managing their local finances is by analyzing the financial ratios of the Regional Revenue and Expenditure Budget that have been established and implemented [6]. Ratio analysis is done by comparing the results achieved from a period compared to the previous period so that it can be known how the trends occur. Some financial ratios can be used to measure the accountability of local government, such as financial independence, effectiveness, efficiency, and regional financial growth ratios. Here the author only describes the three local government financial ratios used to measure the accountability of local 
governments. For regional financial independence, ratios indicate the level of ability of an area to self-finance government activities, development, and services to the community who have paid taxes and retributions as a source of income needed by the region. So the government must be able to improve its regional financial management.

Meanwhile, the effectiveness ratio describes the ability of the Regional Government in realizing the planned locally-generated revenue compared to the target set based on the real potential of the region. The government must be able to control the target revenue of the region with the aim of its realization can be following the target or exceed its target. Moreover, the efficiency ratio describes the comparison between the number of costs incurred to obtain income with the realization of income received. The Medan City Government can increase the accountability of the performance of its government agencies towards the development and implementation of government in the regions. These principles have opened up large opportunities and opportunities for autonomous regions to exercise their authority independently, broadly, real and with responsibility in realizing the welfare of society. The welfare of society can be done by improving the quality of services, empowerment and community participation and regional competitiveness. In realizing good governance, the Medan City Government needs to follow all applicable laws and regulations. One of them is the City of Medan needs to apply the principles of a performance-based budget system that is implemented in stages starting in 2005 .

\section{THEORIES:}

\subsection{Financial Statements}

Public sector reform also means regional financial reform. Regional financial reform in its implementation will also impact on budget reform (budgeting reform) which includes the process of drafting, approving and accountability for the budget [7]-[9]. The financial statements are mainly used to compare the realization of expenditure, transfer and financing revenues with a predetermined budget, assess reporting entities, and help determine compliance with the laws and regulations (government accounting conceptual framework, paragraph 21). The purpose of this Standard Statement is to regulate the presentation of financial statements for general purposes (general purpose financial statements) in order to improve the comparability of financial statements to the budget, between periods, and between entities. Local government financial statements for general purposes from now on referred to as local government financial statements are prepared and presented at least annually to meet a large number of users [10]. The purpose of general financial reporting in local government is to provide information that is useful for decision-making purposes and to demonstrate entity accountability for trusted resources by:

a. Providing information about the sources, allocation, and use of financial resources.

b. Provide information about how the entity funds its activities and meets its cash requirements.

c. Provides information about the financial condition of an entity and changes in it.

d. Providing information that is useful in evaluating an entity's ability to fund its activities and to fulfill its obligations and commitments.

e. Provides competitive information that is useful in evaluating an entity's performance regarding cash services, efficiency, and achievement of objectives.

\subsection{Analysis of Local Government Financial Statements}

To obtain an overview of the financial development of a company, an interpretation or analysis of the financial data of the company is needed, and the financial data will be reflected in the financial statements. Financial reports report both the company's position at a particular time and its operations over the past several periods. There are several methods in the analysis of financial statements. One of the most widely used techniques for analyzing financial statements is financial ratio analysis. There are various types of ratios that can be used to evaluate and interpret financial statements. The results of the calculation of financial ratios need to be interpreted so that the performance of the organization's performance can be evaluated and then certain decisions are made [11].

\subsection{Local Government Financial Performance}

Bastian describes the definition of performance as an illustration of the level of achievement of the implementation of an activity or program or policy in realizing the goals, objectives, mission, and vision of the organization contained in the formulation of strategic planning of an organization. In general, performance is an achievement that can be achieved by an organization within a specified period. Local governments as parties entrusted with the task of running the government, development and social services are obliged to submit their regional financial accountability reports to be assessed whether the local government is successful in carrying out its duties or not. The government's obligation to account for its performance by itself is fulfilled by conveying relevant information in connection with the results of the program carried out to representatives of the people and also community groups who want to want government performance. 


\section{METHODOLOGY:}

\subsection{Population and Sample}

The population in this study is the monthly Medan City Government financial report from 2010 to 2013. Samples from this study were taken with purposive sampling technique. The research sample is a 4-year time dimension so that the number of observations analysis units (4 years x 12 monthly financial reports) are 48 samples from the Medan Government Financial Report.

\subsection{Data Analysis}

Data analysis method used in this study uses multiple linear regression analysis, classical assumption test and hypothesis test. With the multiple regression equation formulation are as follows:

Where:

$$
R K=\beta 0+\beta 1 R P+\beta 2 R E f+\beta 3 R E n+e
$$

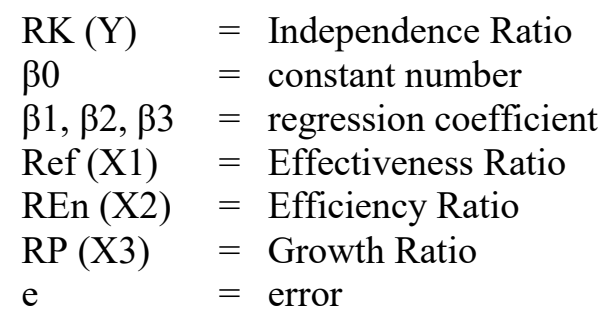

\section{RESULT AND DISCUSSION:}

\subsection{Multicolinearity Test}

According to Santoso in Dwi Priyatno (2008: 39), in a multicollinearity test by looking at the inflation factor (VIF) value in the regression model, if VIF is greater than 5, then the variable has multicollinearity.

Table 1. Multicollinearity

\section{Coefficients ${ }^{\mathrm{a}}$}

\begin{tabular}{|c|c|c|c|c|c|c|c|c|c|c|c|}
\hline \multirow[b]{2}{*}{ Model } & & \multicolumn{2}{|c|}{$\begin{array}{l}\text { Unstandard } \\
\text { ized } \\
\text { Coefficient } \\
\text { s }\end{array}$} & \multirow{2}{*}{ 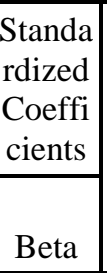 } & \multirow[b]{2}{*}{$\mathrm{T}$} & \multirow[b]{2}{*}{ Sig. } & \multicolumn{3}{|c|}{ Correlations } & \multicolumn{2}{|c|}{ Collinearity Statistics } \\
\hline & & B & \begin{tabular}{|c|} 
Std. \\
Error
\end{tabular} & & & & $\begin{array}{l}\text { Zero- } \\
\text { order }\end{array}$ & Partial & Part & Tolerance & VIF \\
\hline \multirow[t]{4}{*}{1} & (Constant) & 016 & .286 & & -.055 & .957 & & & & & \\
\hline & LN_Ref & .622 & .208 & .484 & 2.986 & .005 & .672 & .451 & .359 & .549 & 1.820 \\
\hline & LN Ren & .318 & .185 & .279 & 1.722 & .094 & .605 & .279 & .207 & .547 & 1.827 \\
\hline & LN_RP & .018 & .121 & .018 & .152 & .880 & .051 & .026 & .018 & .995 & 1.005 \\
\hline
\end{tabular}

a. Dependent Variable: LN_RK

Based on the collinearity statistics test results above, it can be explained that the VIP values of the Natural Logarithm of Effectiveness Ratio, the Logarithm Natural Efficiency Ratio, the Natural Logarithm Growth Ratio show smaller than 10 .

\subsection{Normality test}

Normality tests whether in the regression model, the residual variable has a normal distribution or not. Basic decision making normality test:

- Data is normally distributed, if the sig value (significance) $>0.05$

- Data is not normally distributed, if the sig value (significance) is $<0.05$. 
Table 2. One - Sample Kolmogorov - Smirnov Test

One-Sample Kolmogorov-Smirnov Test

\begin{tabular}{|ll|r|}
\hline & & \multicolumn{2}{|c|}{ Unstandardized Residual } \\
\hline N & & 39 \\
Normal Parameters $^{\mathrm{a}}$ & Mean & .0000000 \\
& Std. & .65427260 \\
& Deviation & .163 \\
Most Extreme Differences & Absolute & .126 \\
& Positive & -.163 \\
& Negative & 1.017 \\
Kolmogorov-Smirnov Z & & .252 \\
Asymp. Sig. (2-tailed) & & .25 \\
\hline
\end{tabular}

a. Test distribution is Normal.

From the results of data processing, the value of Kolmogorov-Smirnov (K-S) is 1,017, and the significance is 0.252. After looking at the table above, it can be concluded that the Kolmogorov-Smirnov (K-S) calculation shows the data in the regression model is normally distributed, where the significance value is more than 0.05 . Where $\alpha=0.05$ (asymp.Sig $=0.252>0.05$ ) To be more explicit, the following shows a graph of histograms and data plots that are usually distributed.

\subsection{Heteroscedasticity Test}

The results of the heteroscedasticity test can be seen in the Scatterplot graph as follows:

\section{Scatterplot}

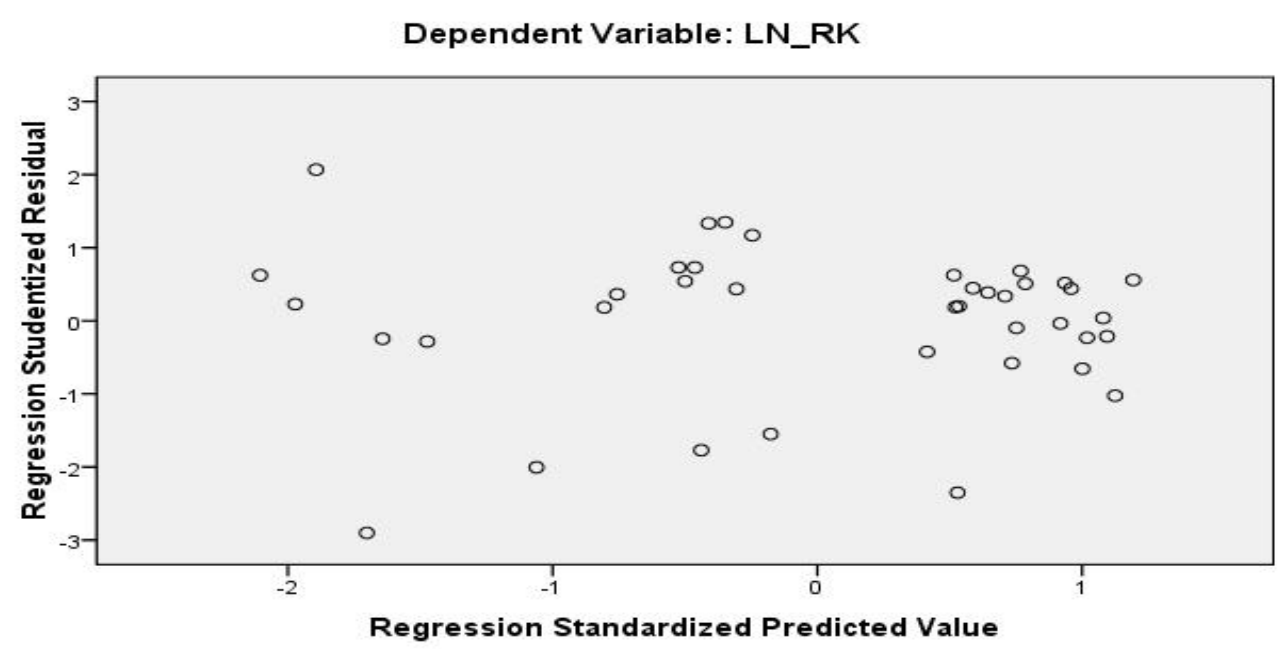

Figure 1. Heteroscedasticity Test

From the Scatterplot graph above, it can be seen that the data does not form a particular pattern, so it can be concluded that this regression model is free from heteroscedasticity problems in the regression model so that the regression model can be used. The existence of dots that spread away from other points due to the observation data which very different from other observational data.

\subsection{Autocorrelation Test}

Detect autocercalation by using the Durbin Watson value compared to the Durbin Watson ( $\mathrm{dl}$ and $\mathrm{du}$ ) table. Criteria if $\mathrm{du}<\mathrm{d}$ count $<4-\mathrm{du}$, there is no autocercalation. 
Table 3. Autocorrelation Test

Model Summary ${ }^{b}$

\begin{tabular}{|c|c|c|c|c|c|c|c|c|c|c|}
\hline \multirow[b]{2}{*}{ Model } & \multirow[b]{2}{*}{$\mathrm{R}$} & \multirow[b]{2}{*}{$\begin{array}{c}\mathrm{R} \\
\text { Square }\end{array}$} & \multirow[b]{2}{*}{$\begin{array}{l}\text { Adjusted } \\
\text { R Square }\end{array}$} & \multirow[b]{2}{*}{$\begin{array}{c}\text { Std. Error } \\
\text { of the } \\
\text { Estimate }\end{array}$} & \multicolumn{5}{|c|}{ Change Statistics } & \multirow[b]{2}{*}{$\begin{array}{l}\text { Durbin- } \\
\text { Watson }\end{array}$} \\
\hline & & & & & $\begin{array}{c}\mathrm{R} \\
\text { Square } \\
\text { Change }\end{array}$ & $\begin{array}{c}\mathrm{F} \\
\text { Change }\end{array}$ & df1 & df2 & $\begin{array}{c}\text { Sig. F } \\
\text { Change }\end{array}$ & \\
\hline 1 & $.704^{\mathrm{a}}$ & .495 & .452 & .68174 & .495 & 11.444 & 3 & 35 & .000 & 1.952 \\
\hline
\end{tabular}

\subsection{Hypothesis testing}

Here is a table of Coefficients showing regression calculations from this study.

Table 4. Hypothesis Test

\begin{tabular}{|c|c|c|c|c|c|c|c|c|c|c|c|}
\hline \multicolumn{12}{|c|}{ Coefficients $^{\mathrm{a}}$} \\
\hline \multirow{2}{*}{\multicolumn{2}{|c|}{ Model }} & \multicolumn{2}{|c|}{$\begin{array}{l}\text { Unstandardized } \\
\text { Coefficients }\end{array}$} & \multirow{2}{*}{\begin{tabular}{|c|} 
Standar \\
dized \\
Coeffic \\
ients \\
\\
Beta
\end{tabular}} & \multirow[b]{2}{*}{$\mathrm{t}$} & \multirow[b]{2}{*}{ Sig. } & \multicolumn{3}{|c|}{ Correlations } & \multicolumn{2}{|c|}{$\begin{array}{l}\text { Collinearity } \\
\text { Statistics }\end{array}$} \\
\hline & & B & $\begin{array}{l}\text { Std. } \\
\text { Error }\end{array}$ & & & & $\begin{array}{l}\text { Zero- } \\
\text { order }\end{array}$ & Partial & Part & $\begin{array}{l}\text { Toler } \\
\text { ance }\end{array}$ & VIF \\
\hline \multirow[t]{4}{*}{1} & $\begin{array}{l}\text { (Consta } \\
\text { nt) }\end{array}$ & -.016 & .286 & & -.055 & .957 & & & & & \\
\hline & $\begin{array}{l}\mathrm{LN} \_\mathrm{RE} \\
\mathrm{f}\end{array}$ & .622 & .208 & .484 & 2.986 & .005 & .672 & .451 & .359 & .549 & 1.820 \\
\hline & $\begin{array}{l}\mathrm{LN} \_\mathrm{RE} \\
\mathrm{n}\end{array}$ & .318 & .185 & .279 & 1.722 & .094 & .605 & .279 & .207 & .547 & 1.827 \\
\hline & LN_RP & .018 & .121 & .018 & .152 & .880 & .051 & .026 & .018 & .995 & 1.005 \\
\hline
\end{tabular}

a. Dependent Variable: LN_RK

\subsection{T test (Partial Test)}

The results of the $t$ test based on the results of the SPSS output can be seen in the Coefficients table below:

Table 5. Partial Hypothesis Test (T Test)

\section{Coefficients $^{\mathrm{a}}$}

\begin{tabular}{|c|c|c|c|c|c|c|}
\hline \multirow{2}{*}{\multicolumn{2}{|c|}{ Model }} & \multicolumn{2}{|c|}{$\begin{array}{l}\text { Unstandardized } \\
\text { Coefficients }\end{array}$} & \multirow{2}{*}{$\begin{array}{c}\begin{array}{c}\text { Standardized } \\
\text { Coefficients }\end{array} \\
\text { Beta }\end{array}$} & \multirow[b]{2}{*}{$\mathrm{t}$} & \multirow[b]{2}{*}{ Sig. } \\
\hline & & B & Std. Error & & & \\
\hline 1 & (Constant) & -.016 & .286 & & -.055 & .957 \\
\hline & LN_Ref & .622 & .208 & .484 & 2.986 & .005 \\
\hline & LN_Ren & .318 & .185 & .279 & 1.722 & .094 \\
\hline & LN_RP & .018 & .121 & .018 & .152 & .880 \\
\hline
\end{tabular}

a. Dependent Variable: LN_RK

Based on Table 5, the results can be analyzed as follows:

- The LN_REf (X1) variable has a $0.005 \mathrm{sig}<0.05$ meaning that it is significant. Significant here means Ho is rejected and Ha is accepted. That is, the LN_REf (X1) variable partially affects LN_RK (Y).

- The LN REn (X2) variable has a sig. 0.094> 0.05 means that it is not significant. Not significant here means that Ho is accepted and Ha is rejected ... That is, the LN_REn (X2) variable partially does not affect LN_RK (Y). 
- The LN_RP (X3) variable has a sig. $0.880>0.05$ means that it is not significant. Not significant here means that Ho is accepted and Ha is rejected. That is, the LN_RP variable (X3) partially does not affect LN_RK (Y).

\subsection{F-Test (Simultaneous Test)}

The F test results based on the results of the SPSS output can be seen in the follwing table.

Table 6. F Test (Simultaneous Test)

\begin{tabular}{|c|c|c|c|c|c|c|}
\hline \multicolumn{7}{|c|}{ ANOVA $^{b}$} \\
\hline & & Sum of Squares & $\mathrm{df}$ & Mean Square & $\mathrm{F}$ & Sig. \\
\hline \multirow[t]{3}{*}{1} & Regression & 15.957 & 3 & 5.319 & 11.444 & $.000^{\mathrm{a}}$ \\
\hline & Residual & 16.267 & 35 & .465 & & \\
\hline & Total & 32.224 & 38 & & & \\
\hline
\end{tabular}

Based on the table above where Fcount 11,444> Ftable 2,80 and Sig value 0,000, meaning significant. Significant here means, the variable Effectiveness Ratio (X1), Efficiency Ratio (X2) and Growth Ratio (X3) together (simultaneously) affect the independence ratio (Y).

\subsection{Determination Coefficient Test (R2)}

In this multiple linear regression test also analyzed the magnitude of the coefficient of determination (R2) as a whole. The coefficient of determination is to determine the effect of all independent variables $(\mathrm{X})$ on the dependent variable $(\mathrm{Y})$.

Table 7. Results of Determination Coefficient Analysis

\begin{tabular}{|c|c|c|c|c|c|c|c|c|c|}
\hline \multicolumn{10}{|c|}{ Model Summary } \\
\hline \multirow[b]{2}{*}{ Model } & \multirow[b]{2}{*}{$\mathrm{R}$} & \multirow[b]{2}{*}{ R Square } & \multirow[b]{2}{*}{$\begin{array}{l}\text { Adjusted } \\
\text { R Square }\end{array}$} & \multirow[b]{2}{*}{$\begin{array}{l}\text { Std. Error } \\
\text { of the } \\
\text { Estimate }\end{array}$} & \multicolumn{5}{|c|}{ Change Statistics } \\
\hline & & & & & $\begin{array}{c}\mathrm{R} \\
\text { Square } \\
\text { Change }\end{array}$ & F Change & df1 & $\mathrm{df} 2$ & Sig. F Change \\
\hline 1 & $.704^{\mathrm{a}}$ & .495 & .452 & .68174 & .495 & 11.444 & 3 & 35 & .000 \\
\hline
\end{tabular}

Table 7 describes the results of calculations with SPSS obtained the value of adjusted R2 of 0.452 coefficient indicates that $45.2 \%$ change in the independence ratio of Medan City Government is caused by the Effectiveness Ratio, Efficiency Ratio, and Growth Ratio, while the remaining $54.8 \%$ due to other variables not examined in this study outside the model that is activity ratio, debt service coverage ratio (DSCR).

\subsection{Discussion}

The results of the data analysis above show that partially the ratio of effectiveness has a significant effect on the independence of Medan City Government, whereas in the previous study, [12] the ratio of effectiveness did not have a significant partial effect on the independence of Soppeng Regency. The regression model that is formed from the results of the regression analysis shows that each increase in the effectiveness ratio of one unit will be followed by an increase in the Medan City Government independence ratio of 0.484 . Meanwhile, Medan City Government effectiveness ratio is quite active with the increase and decrease in 4 years, such as 2010/2013 (January to December). Nevertheless, Medan City Government can continue to improve the effectiveness of its regional finances by optimizing the utilization of nine business sectors it owns, such as agriculture, mining and quarrying, processing industries, electricity, gas and water supply, construction, trade, hotels and restaurants, transportation and communication, finance, leasing and company services, as well as services.

Based on the results of partial regression analysis, the efficiency ratio did not significantly influence the independence ratio of Medan City Government while in the previous study the efficiency ratio had a significant effect. It means that what is targeted is not necessarily the same as the actual realization. The target can be higher than 
realization, and on the contrary, the target can be smaller than realization. The results of regression analysis partially showed that the growth ratio did not significantly influence the independence ratio of Medan City Government, whereas in the previous study (Yanti) the growth ratio had no significant effect on the independence ratio. It shows that the growth ratio does not have a positive impact on the independence ratio of Medan city government.

While simultaneously, it can be seen that the independent variables used, such as the effectiveness ratio (X1), efficiency ratio (X2) and growth ratio (X3) have a significant effect on the dependent variable, such as the independence ratio $(\mathrm{Y})$, in the previous research, the ratio of effectiveness, efficiency ratio, and growth ratio also influence simultaneously to the independence ratio. The R Square value of 0.452 indicates that the independence ratio in Medan City Government can be explained by the independent variables, such as the ratio of effectiveness, efficiency ratio and growth ratio of $45.2 \%$. While the rest, $54.8 \%$ is explained by other variables outside the model other than the variable ratio of effectiveness, efficiency ratio and growth ratio (activity ratio, debt service ratio (DSCR)).

Meanwhile, Yanti's in the previous research has in common that partially only one variable from five variables used in his research is significant to the independence ratio, such as the efficiency ratio, and in the present study which is partially significant such as the effectiveness ratio. And simultaneously to the previous researcher also together from five variables used in his research such as independence, effectiveness, efficiency, growth, activity, and debt service ratios (DSCR) which is significant to the ratio independence, it has in common with the research that the authors examined the effectiveness ratio, efficiency ratio and growth ratio which is also significant simultaneously to the independence ratio of the financial performance of Medan City Government.

\section{CONCLUSION:}

The financial performance of the Medan city government in the past four years has been well proven. The Independence of city government of Medan in the past four years has proven to be independent. Partially the effectiveness ratio of Medan City Government has a significant effect on Medan City Government financial performance in the last four years (2010-2013). The efficiency ratio of Medan City Government has no significant effect on the independence of locally-generated revenue in the last four years (2010-2013) while the growth ratio of Medan City Government has no significant effect on the independence of locally-generated revenue in the last four years (20102013). Simultaneously the ratio of effectiveness, efficiency ratio, and growth ratio significantly influence the independence of locally-generated revenue in the last four years (2010-2013).

\section{REFERENCES:}

1. Mardiasmo, Otonomi dan Manajemen Keuangan Daerah. Yogyakarta: Andi Offset, 2007.

2. Sugiyono, Metode Penelitian Kuantitatif dan Kualitatif R dan D. Bandung: Alfabeta, 2009.

3. Sugiyono, Metodologi Penelitian Bisnis. Bandung: PT. Alfabeta, 2004.

4. A. K. Sari, H. Saputra, dan A. P. U. P. U. Siahaan, "Financial Distress Analysis on Indonesia Stock Exchange Companies," Int. J. Innov. Res. Multidiscip. F., vol. 4, no. 3, hal. 73-74, 2018.

5. A. K. Sari, H. Saputra, dan A. P. U. Siahaan, "Effect of Fiscal Independence and Local Revenue Against Human Development Index," Int. J. Bus. Manag. Invent., vol. 6, no. 7, hal. 62-65, 2017.

6. A. Halim, Akuntansi Keuangan Daerah. Jakarta: Salemba Empat, 2005.

7. H. M. Ritonga, H. A. Hasibuan, dan A. P. U. Siahaan, "Credit Assessment in Determining The Feasibility of Debtors Using Profile Matching,” Int. J. Bus. Manag. Invent., vol. 6, no. 1, hal. 73-79, 2017.

8. H. A. Hasibuan, R. B. Purba, dan A. P. U. Siahaan, "Productivity Assessment (Performance, Motivation, and Job Training) using Profile Matching," Int. J. Econ. Manag. Stud., vol. 3, no. 6, hal. 73-77, 2016.

9. Y. Rossanty, S. Aryza, M. D. T. P. Nasution, dan A. P. U. Siahaan, "Design Service of QFC And SPC Methods in the Process Performance Potential Gain and Customers Value in a Company," Int. J. Civ. Eng. Technol., vol. 9, no. 6, hal. 820-829, 2018.

10. I. Bastian, Akuntansi Sektor Publik. Yogyakarta: Andi Offset, 2005.

11. W. C. Rivenbark, D. J. Roenigk, dan G. S. Allison, "Conceptualizing Financial Condition In Local Government," J. Public Budgeting, Account. Financ. Manag., vol. 22, no. 2, hal. 149-177, Mar 2010.

12. Yanti, Skripsi: Analisis Rasio Sebagai Indikator Kinerja Keuangan Pemerintah Kabupaten Sopeng. Makassar: Universitas Hasanuddin, 2011. 